Abstracta Iranica Abstracta Iranica

Revue bibliographique pour le domaine irano-aryen

Volume 30 | 2010

Comptes rendus des publications de 2007

\title{
A Residence of Eight Years in Persia among the Nestorian Christians with Notices of the Muhammedans. Piscataway NJ, Gorgias Press, 2006, 512 p.
}

Christelle Jullien

\section{(2) OpenEdition}

\section{Journals}

Édition électronique

URL : http://journals.openedition.org/abstractairanica/37892

DOI : 10.4000/abstractairanica.37892

ISSN : 1961-960X

Éditeur :

CNRS (UMR 7528 Mondes iraniens et indiens), Éditions de l'IFRI

\section{Édition imprimée}

Date de publication : 8 avril 2010

ISSN : 0240-8910

\section{Référence électronique}

Christelle Jullien, "A Residence of Eight Years in Persia among the Nestorian Christians with Notices of the Muhammedans. Piscataway NJ, Gorgias Press, 2006, 512 p. », Abstracta Iranica [En ligne], Volume $30 \mid$ 2010, document 209, mis en ligne le 08 avril 2010, consulté le 26 septembre 2020. URL : http:// journals.openedition.org/abstractairanica/37892; DOI : https://doi.org/10.4000/abstractairanica 37892

Ce document a été généré automatiquement le 26 septembre 2020.

Tous droits réservés 


\section{A Residence of Eight Years in Persia among the Nestorian Christians with Notices of the Muhammedans. Piscataway NJ, Gorgias Press, 2006, $512 \mathrm{p}$.}

Christelle Jullien

Justin Perkins (1805-1869), pasteur américain, raconte en 14 chapitres sa mission depuis Malte jusqu'à Constantinople, l'Arménie et enfin la région d'Urmia, consignant les événements politiques et ecclésiaux de son temps. Cette relation de voyage se présente comme un carnet de bord tenu de 1834 à 1841. Une brève introduction expose l'histoire des chrétiens dits nestoriens et une description des débuts de la mission américaine au Moyen-Orient. Sa narration fourmille de détails sur la vie quotidienne de cette région à cette époque: la scolarisation des enfants, le clergé chaldéen, les fêtes villageoises, les coutumes des minorités religieuses (notamment des juifs), les croyances (les traditions circulant sur St Thomas par exemple). Cet ouvrage apporte son éclairage sur les activités missionnaires occidentales dans ces espaces au cours du XIX ${ }^{\mathrm{e}}$ siècle.

\section{INDEX}

Thèmes : 6.3. Autres religions 
AUTEURS

CHRISTELLE JULLIEN

CNRS/Mondes iranien et indien - Paris 